\title{
An exploration study on influential factors on customer relationship management
}

\author{
Naser Azad", Amir Hassanjani Roshan and Somayeh Hozouri
}

Department of Management, Islamic Azad University, South Tehran Branch, Tehran, Iran

\begin{tabular}{|c|c|}
\hline CHRON I CLE & ABS TRACT \\
\hline $\begin{array}{l}\text { Article history: } \\
\text { Received January 15, } 2013 \\
\text { Accepted August 12, } 2013 \\
\text { Available online } \\
\text { August } 14 \quad 2013 \\
\text { Keywords: } \\
\text { Customer relationship } \\
\text { management } \\
\text { Factor analysis } \\
\text { CRM }\end{array}$ & $\begin{array}{l}\text { These days, we see an increasing competition among different business owners and they strive } \\
\text { for customer retention. Customer relationship management plays an important role to increase } \\
\text { business performance and attracting new customers in an attempt to have more market shares. } \\
\text { One primary concern is to find more about important factors influencing customers being } \\
\text { satisfied with different services they may receive. This paper performs an empirical } \\
\text { investigation to find important factors influencing customer relationship management (CRM) in } \\
\text { information and communication firm is city of Tehran, Iran. The survey uses factor analysis to } \\
\text { find important factors using a questionnaire consist of } 27 \text { variables. Cronbach alpha is } \\
\text { calculated as 0.861, which validates the questionnaire. The survey detects six factors } \\
\text { influencing CRM learning performance attributes, enterprise resource planning, perception } \\
\text { attributes, structure oriented, perception image and organizational resources. }\end{array}$ \\
\hline
\end{tabular}

\section{Introduction}

During the past few years, there have been tremendous efforts on investigating different factors on customer relationship management (CRM) since many business models have substantially invested in CRM (Mandják \& Szántó, 2010; Mandják \& Szántó, 2010; Nguyen \& Mutum, 2012; Chikweche \& Fletcher, 2013). Smith and Chang (2010), for instance, investigated whether an investment CRM generates the anticipated benefits. They reported that firms that pay more attention to a customercentric approach could benefit significantly from the implementation of CRM systems. There were no differences in the degree or focus of applying attributable to industry differences. Lambert (2009) stated that CRM can be stated as a strategic, process-oriented, cross-functional, value-creating for buyer and seller, and facilitate for accessing superior financial performance. However, we require for a more holistic view of cross-functional as it is associated with CRM.

* Corresponding author.

E-mail addresses: dr.naserazad@yahoo.com (N. Azad)

(C) 2013 Growing Science Ltd. All rights reserved. doi: $10.5267 /$ j.dsl.2013.08.003 
Lambert (2009) described a macro level cross-functional view of CRM and provided a structure for managing business-to-business relationships to co-create value and increase shareholder value. Lambert reported in a framework that managers could implement a cross-functional, cross-firm, CRM process in business-to-business relationships. Lin et al. (2010) investigated the impacts of different dimensions of CRM on innovation capabilities. They identified five dimensions of CRM including information sharing, customer involvement, long-term partnership, joint problem-solving, and technology-based CRM and five aspects of innovation capability including product, process, administrative, marketing, and service innovations. Sophonthummapharn (2009) developed a comprehensive research framework for understanding the adoption of techno-relationship innovations. The author also examined the factors influencing the adoption of electronic customer relationship management (eCRM) applications. They reported the top five influential factors including compatibility, industry pressure, customer pressure, subjective norm, and attitude. Jamali et al. (2013) aimed to develop a valid and reliable technique for assessing and measuring the management relationship level with customers in e-libraries. Besides, the research tried to detect how successful Yazd University Libraries met students' expectations, as a guideline to take steps towards improving its services. Kim et al. (2012) considered a means to create competitive advantage for a company, as well as influence organizational performance. Ata and Toker (2012) investigated the effect of customer relationship management adoption in business-to-business markets. Wang and Feng (2012) investigated CRM capabilities in terms of measurement, antecedents and consequences. Ranjan and Bhatnagar (2011) investigated the role of knowledge management and analytical CRM in business based on data mining based framework.

\section{The proposed method}

The proposed model of this paper uses factor analysis (Azad \& Hassanabadi, 2013; Azad \& Mohammadi, 2013) to determine important factors influencing data security in information and communication organization in city of Tehran, Iran. The study designs a questionnaire consists of 27 questions and in Likert scale. The sample size is calculated as follows,

$n=\frac{N \times z_{\alpha / 2}^{2} \times p \times q}{\varepsilon^{2} \times(N-1)+z_{\alpha / 2}^{2} \times p \times q}$,

where $N$ is the population size, $p=1-q$ represents the yes/no categories, $z_{\alpha / 2}$ is CDF of normal distribution and finally $\varepsilon$ is the error term. Since we have $p=0.5, z_{\alpha / 2}=1.96$ and $N=1100$, the number of sample size is calculated as $n=203$. Cronbach alpha has been calculated as 0.891 in preliminary stage and final 0.856 in final stage, which are statistically acceptable. In addition, Kaiser-MeyerOlkin Measure of Sampling Adequacy is calculated as 0.74, which is within an acceptable limit and validates the results. Since factor analysis is sensitive on skewness of factors, we have decided to delete seven questions. Fig. 1 demonstrates Scree plot on questions of the survey. Table 1 demonstrates 27 items of the designed questionnaire.

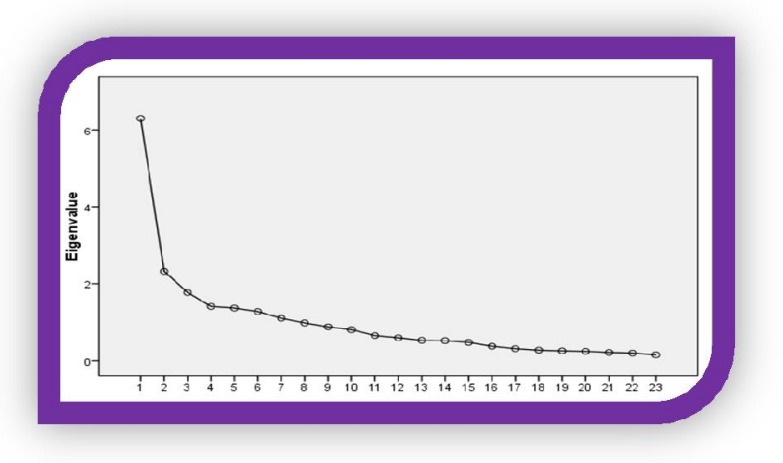

Fig. 1. The Scree plot 
Table 1

\begin{tabular}{|c|c|}
\hline Factor & Description \\
\hline 1 & Theoretical methods for measuring Customer Satisfaction Such surveys (Zip - Phone - Email) \\
\hline 2 & Quality of services offered by the company \\
\hline 3 & Interpersonal Influence \\
\hline 4 & Subjective norm \\
\hline 5 & Moral agency \\
\hline 6 & information technology \\
\hline 7 & customer retention rates \\
\hline 8 & provide after-sale service \\
\hline 9 & resolve customer complaints \\
\hline 10 & According to the preferences and expectations Customer \\
\hline 11 & functional and flexible planning \\
\hline 12 & Creating a Customer orientation \\
\hline 13 & Product lines and services \\
\hline 14 & managing organization as a network \\
\hline 15 & identifying opportunities and conflicts \\
\hline 16 & Objective methods of measuring customer satisfaction \\
\hline 17 & Ensuring return on investment \\
\hline 18 & Value Customer received of company \\
\hline 19 & Internal standards (process control and improvement \\
\hline 20 & The advertising of products or services \\
\hline 21 & Structural factors - Cultural \\
\hline 22 & Company leadership style \\
\hline 23 & Age, number of years of experience of staff \\
\hline 24 & Imagine the customer before the company \\
\hline 25 & Customer attitudes to product quality, service, compared with his expectations \\
\hline 26 & Develop interest and motivate organizations to improve the quality of products and services offered to customers \\
\hline 27 & Minor deviations of customer expectations \\
\hline
\end{tabular}

After performing preliminary analysis, we have extracted communalities with major factors and Table 2 summarizes the results of our survey.

Table 2

The summary of communalities

\begin{tabular}{ccc}
\hline & Communalities & Extraction \\
\cline { 2 - 3 } & Initial & .431 \\
\hline VAR00001 & 1.000 & .726 \\
\hline VAR00002 & 1.000 & .601 \\
VAR00004 & 1.000 & .738 \\
VAR00005 & 1.000 & .668 \\
VAR00006 & 1.000 & .745 \\
VAR00007 & 1.000 & .621 \\
VAR00008 & 1.000 & .683 \\
VAR00009 & 1.000 & .646 \\
VAR00010 & 1.000 & .731 \\
VAR00011 & 1.000 & .698 \\
VAR00013 & 1.000 & .646 \\
\hline VAR00014 & 1.000 & .618 \\
VAR00015 & 1.000 & .686 \\
VAR00016 & 1.000 & .610 \\
VAR00017 & 1.000 & .631 \\
VAR00018 & 1.000 & .756 \\
\hline VAR00019 & 1.000 & .693 \\
\hline VAR00022 & 1.000 & .721 \\
\hline VAR00023 & 1.000 & .739 \\
\hline VAR00025 & 1.000 & .793 \\
\hline VAR00026 & 1.000 & .684 \\
\hline
\end{tabular}

In addition, we have extracted important factors using principal component analysis and Table 3 to Table 5 demonstrate the survey before and after rotation happen. 
Table 3

The results of total variance explained

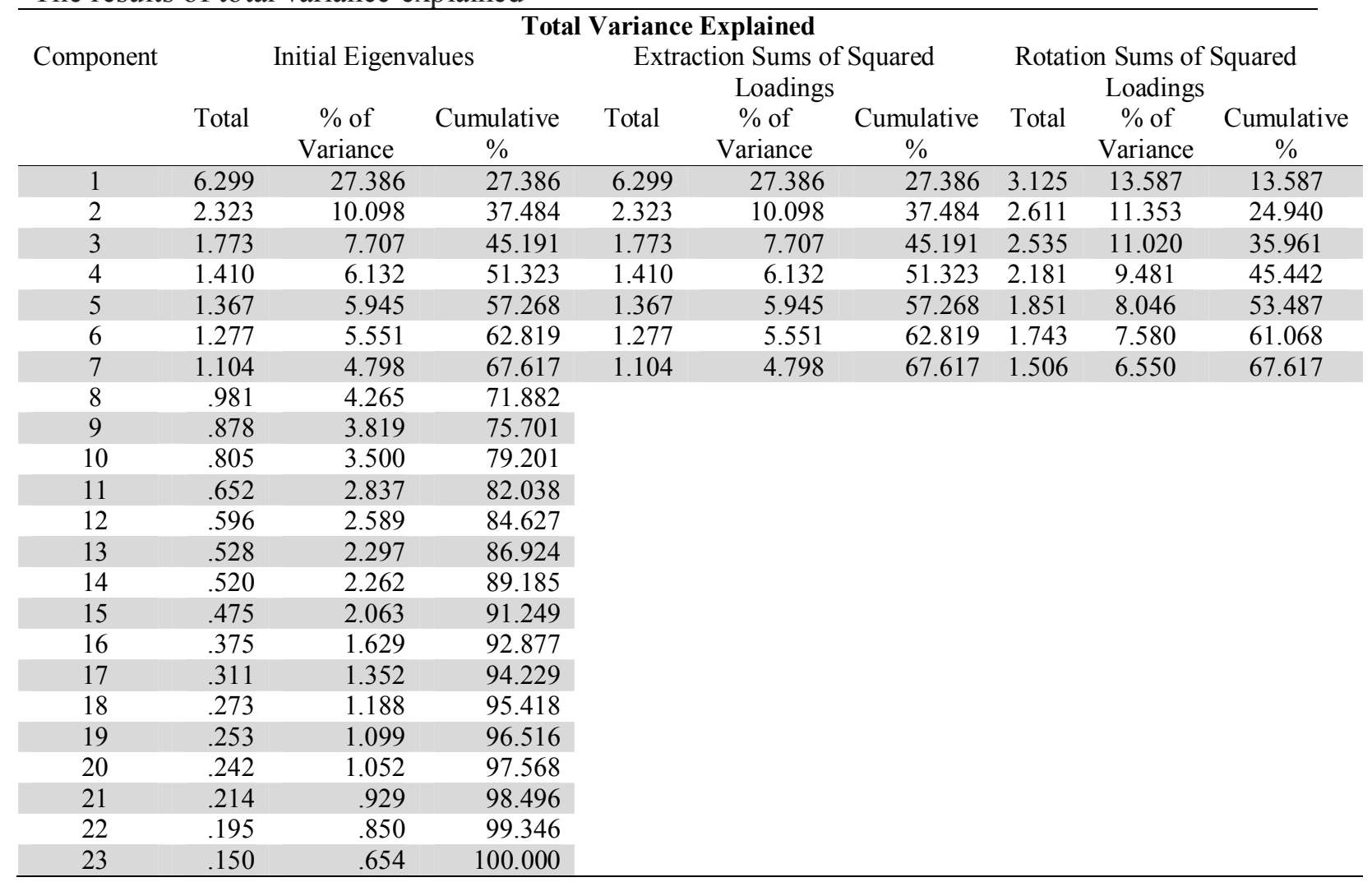

Table 4

The results of principal component analysis before rotation

\begin{tabular}{|c|c|c|c|c|c|c|c|}
\hline \multicolumn{8}{|c|}{ Component Matrix $^{\mathrm{a}}$} \\
\hline & 1 & 2 & 3 & 4 & 5 & 6 & 7 \\
\hline VAR00022 & .688 & & & & & & \\
\hline VAR00025 & .660 & -.390 & & & & & -.371 \\
\hline VAR00010 & .634 & & & & & & \\
\hline VAR00004 & .631 & -.338 & & & & & \\
\hline VAR00027 & .631 & & & & & & -.390 \\
\hline VAR00026 & .601 & & & & & -.441 & \\
\hline VAR00014 & .597 & & .445 & & & & \\
\hline VAR00005 & .574 & & -.378 & & -.367 & & \\
\hline VAR00023 & .566 & -.335 & -.332 & & & & \\
\hline VAR00002 & .562 & & & -.375 & & & \\
\hline VAR00006 & .553 & & & -.510 & & & \\
\hline VAR00024 & .551 & -.353 & & .503 & & & \\
\hline VAR00018 & .550 & & & .429 & & & \\
\hline VAR00008 & .428 & .348 & -.379 & & & & \\
\hline VAR00017 & .432 & .605 & & & & & \\
\hline VAR00009 & .437 & .583 & & & & & \\
\hline VAR00011 & & .500 & & & .490 & & -.342 \\
\hline VAR00015 & & .517 & .561 & & & & \\
\hline VAR00016 & .500 & & .541 & & & & \\
\hline VAR00013 & .395 & .393 & -.498 & & & & \\
\hline VAR00007 & .529 & & & & -.628 & & \\
\hline VAR00019 & .443 & & & & .335 & -.556 & \\
\hline VAR00001 & .355 & & & & & .396 & \\
\hline
\end{tabular}


Table 5

The summary of principal component analysis after rotation

\begin{tabular}{|c|c|c|c|c|c|c|c|}
\hline & \multicolumn{7}{|c|}{ Component } \\
\hline & 1 & 2 & 3 & 4 & 5 & 6 & 7 \\
\hline VAR00025 & .795 & & & & & & \\
\hline VAR00027 & .759 & & & & & & \\
\hline VAR00010 & .720 & & & & & & \\
\hline VAR00004 & .540 & & & & & .363 & \\
\hline VAR00026 & .523 & & & & .478 & & \\
\hline VAR00008 & & .749 & & & & & \\
\hline VAR00009 & & .738 & & & & & \\
\hline VAR00017 & & .494 & & .398 & .372 & & \\
\hline VAR00005 & .341 & .462 & & & & .384 & .392 \\
\hline VAR00018 & & .359 & & & & & .331 \\
\hline VAR00023 & & & .769 & & & & \\
\hline VAR00024 & .391 & & .740 & & & & \\
\hline VAR00022 & & & .714 & & & & \\
\hline VAR00016 & & & & .741 & & & \\
\hline VAR00015 & & & & .724 & & & \\
\hline VAR00014 & .419 & & & .540 & & & \\
\hline VAR00001 & & & & .427 & & & \\
\hline VAR00019 & & & & & .837 & & \\
\hline VAR00013 & & .460 & & & .618 & & \\
\hline VAR00002 & & & .428 & & & .691 & \\
\hline VAR00006 & & .460 & & & & .584 & \\
\hline VAR00011 & & .390 & & & & & -.742 \\
\hline VAR00007 & & .407 & & & & & .687 \\
\hline
\end{tabular}

As we can observe from the results of Table 5, we may extract six important factors influencing on data security. Next, we explain all these factors in details.

\section{The results}

The implementation of factor analysis helps us group different factors and find better insight on market development.

\subsection{Measurement attributes}

The first factor is associated with the measurement attributes and it includes four factors including improving quality of product and services, traditional methods to get customers' feedbacks, explicit observations for measuring quality and resolving existing conflicts. Table 6 summarizes the results of our findings.

Table 6

The summary of different components associated with measurement attributes

\begin{tabular}{lcccc}
\hline Option & Factor weight & Eigenvalue & \% of variance & Accumulated \\
\hline Improving quality of product and services & .775 & & & \\
Traditional methods to get customers' feedbacks & .716 & 2.489 & 62.223 & 62.223 \\
Explicit observations for measuring quality & .784 & & & \\
Resolving existing conflicts & .750 & & & \\
\hline Cronbach alpha $=0.80$ & & &
\end{tabular}

As we can observe from the results of Table 6, improving quality of product and services is the most important factor followed by traditional methods to get customers' feedbacks, explicit observations for measuring quality and resolving existing conflicts. 


\subsection{The second factor: Integrated system}

The second factor is associated with integrated system, which consists of four factors summarized in Table 7 as follows,

\section{Table 7}

The summary of different components associated with integrated system

\begin{tabular}{lcccc}
\hline Option & Factor weight & Eigenvalue & \% of variance & Accumulated \\
\hline Managing firm in forms of network & .781 & & & 51.241 \\
Recognizing opportunities and threats & .807 & 2.562 & 51.241 & \\
Leadership style & .668 & & & \\
\hline Information technology & .672 & & & \\
\hline
\end{tabular}

According to the results of Table 7, managing firm in forms of network is the most important factor followed by recognizing opportunities and threats, leadership style and information technology.

\subsection{The third factor: Perception components}

Integrated system is the third factor and it includes three items summarized in Table 8 as follows,

\section{Table 8}

The summary of different components associated with perception components

\begin{tabular}{lcccc}
\hline Option & Factor weight & Eigenvalue & \% of variance & Accumulated \\
\hline Subjective norm & .863 & & & 69.782 \\
Moral agency & .863 & 2.093 & 69.782 & \\
\hline Interpersonal Influence & .778 & & & \\
\hline Cronbach alpha $=0.78$ & & &
\end{tabular}

Cronbach alpha $=0.78$

According to the results of Table 8, subjective norms as well as moral agency are the most influential factors followed by interpersonal influence.

\subsection{The fourth factor: Structure oriented}

Structure oriented is the fourth factor and it includes four items summarized in Table 9 as follows,

\section{Table 9}

The summary of different components associated with structure oriented

\begin{tabular}{lcccc}
\hline Option & Factor weight & Eigenvalue & \% of variance & Accumulated \\
\hline Advertisement on products and services & .780 & & & \\
Cultural features & .798 & 1.530 & 38.238 & 38.238 \\
Rate of customer retention & .525 & & \\
Flexible programs & -0.98 & & & \\
\hline Cronbach alpha $=0.40$ & & &
\end{tabular}

According to the results of Table 9, cultural features are the most important issues followed by advertisement on products and services.

\subsection{The fifth factor: Perception from product and services}

The fifth factor is associated with perception from product and services, which consists of three factors summarized in Table 10 as follows, 
Table 10

The summary of different components associated with organizational learning

\begin{tabular}{lcccc}
\hline Option & Factor weight & Eigenvalue & \% of variance & Accumulated \\
\hline Perception of customer from products & .75 & & & \\
Past experience from the firm & .806 & 1.729 & 57.625 & 57.625 \\
Value received from products and services & .718 & & & \\
\hline Cronbach alpha $=0.63$ & & &
\end{tabular}

According to the results of Table 10, past experience from the firm is the most important factor followed by Value received from products and services and Perception of customer from products.

\subsection{The sixth factor: Organizational resources}

The last factor is associated with organizational resources, which consists of three sub-components summarized in Table 11 as follows,

\section{Table 11}

The summary of different components associated with feasibility study

\begin{tabular}{lcccc}
\hline Option & Factor weight & Eigenvalue & \% of variance & Accumulated \\
\hline Strategy for providing product and services & .857 & & & \\
Personal characteristics of products & .804 & 1.424 & 47.476 & 47.476 \\
Return of investment & -0.209 & & & \\
\hline Cronbach alpha $=0.40$ & & & &
\end{tabular}

Cronbach alpha $=0.40$

According to the results of Table 11, strategy for providing product and services is number one priority followed by personal characteristics of products.

\section{Conclusion}

This paper has presented an empirical investigation to detect important factors influencing customer relationship management in information and communication technology firm in city of Tehran, Iran. Using a questionnaire in Likert scale, the survey used factor analysis to detect influencing factors in CRM. The survey has detected six factors influencing CRM learning performance attributes, enterprise resource planning, perception attributes, structure oriented, perception image and organizational resources.

The first factor is associated with the measurement attributes and it includes four factors including improving quality of product and services, traditional methods to get customers' feedbacks, explicit observations for measuring quality and resolving existing conflicts. In our survey, improving quality of product and services is the most important factor followed by traditional methods to get customers' feedbacks, explicit observations for measuring quality and resolving existing conflicts. The second factor is associated with integrated system, which consists of four factors where managing firm in forms of network is the most important factor followed by recognizing opportunities and threats, leadership style and information technology. Integrated system is the third factor and it includes three items where subjective norms as well as moral agency are the most influential factors followed by interpersonal influence. Structure oriented is the fourth factor and it includes four items where cultural features are the most important issues followed by advertisement on products and services. The fifth factor is associated with perception from product and services, which consists of three factors where past experience from the firm is the most important factor followed by Value received from products and services and Perception of customer from products. The last factor is associated with organizational resources, which consists of three sub-components where strategy for providing product and services is number one priority followed by personal characteristics of products. 


\section{Acknowledgement}

The authors would like to thank anonymous referees for constructive comments on earlier version of the paper.

\section{References}

Ata, U. Z., \& Toker, A. (2012). The effect of customer relationship management adoption in business-to-business markets. Journal of Business \& Industrial Marketing, 27(6), 497-507.

Azad, N., \& Hassanabadi, M. (2013). An empirical investigation on factors influencing on brand loyalty. Management Science Letters, 3(7), 2113-2118.

Azad, N., \& Mohammadi, M.(2013). An empirical survey on factors influencing on packaging dairy products. Management Science Letters, 3(7), 1901-1906.

Chikweche, T., \& Fletcher, R. (2013). Customer relationship management at the base of the pyramid: myth or reality?. Journal of Consumer Marketing,30(3), 295-309.

Jamali, R., Moshabaki, A., Aramoon, H., \& Alimohammadi, A. (2013). Customer relationship management in electronic environment. The Electronic Library, 31(1), 119-130.

Kim, M., Park, J. E., Dubinsky, A. J., \& Chaiy, S. (2012). Frequency of CRM implementation activities: a customer-centric view. Journal of Services Marketing, 26(2), 83-93.

Lambert, D. M. (2009). Customer relationship management as a business process. Journal of Business \& Industrial Marketing, 25(1), 4-17.

Lin, R. J., Chen, R. H., \& Chiu, K. K. S. (2010). Customer relationship management and innovation capability: an empirical study. Industrial Management \& Data Systems, 110(1), 111-133.

Mainela, T., \& Ulkuniemi, P. (2012). Personal interaction and customer relationship management in project business. Journal of Business \& Industrial Marketing, 28(2), 3-3.

Mandják, T., \& Szántó, Z. (2010). How can economic sociology help business relationship management?. Journal of Business \& Industrial Marketing, 25(3), 202-208.

Nguyen, B., \& Mutum, D. S. (2012). A review of customer relationship management: successes, advances, pitfalls and futures. Business Process Management Journal, 18(3), 400-419.

Ranjan, J., \& Bhatnagar, V. (2011). Role of knowledge management and analytical CRM in business: data mining based framework. The Learning Organization, 18(2), 131-148.

Smith, M., \& Chang, C. (2010). Improving customer outcomes through the implementation of customer relationship management: Evidence from Taiwan. Asian Review of Accounting, 18(3), 260-285.

Sophonthummapharn, K. (2009). The adoption of techno-relationship innovations: a framework for electronic customer relationship management. Marketing Intelligence \& Planning, 27(3), 380-412.

Wang, Y., \& Feng, H. (2012). Customer relationship management capabilities: Measurement, antecedents and consequences. Management Decision, 50(1), 115-129. 